\title{
Clinical characteristics of newly diagnosed tuberculosis patients with respiratory failure
}

\author{
C Permpikul', S Tongyoo, W Lekpittaya, P Thamrongpairoj \\ From ESICM LIVES 2015 \\ Berlin, Germany. 3-7 October 2015
}

\section{Introduction}

Respiratory failure from tuberculosis is not as common as other community acquired infection. Delay in diagnosis of tuberculosis thus poses significant impact on disease management and ICU infection control. We report here the clinical characteristics of this condition in order to render better diagnosis and early management.

\section{Methods}

A retrospective study in inpatients whose a new diagnosis of tuberculosis was made after admission. The information reviewed included clinical characteristics, laboratory results and outcomes.

\section{Results}

Among 738 patients with tuberculosis who were admitted during January 2011 and December 2013, 60 were newly diagnosed. Of these, 35 (58.3\%) patients had respiratory failure. When comparing those who had respiratory failure (RF) and those who did not (no RF), there was no significant difference in age (RF $47.3 \pm$ 16.9 VS no RF $44.5 \pm 15.8, \mathrm{P}=0.51)$, male sex $(71.4 \%$ VS $68.0 \%, \mathrm{P}=0.76)$, BMI $(17.9 \pm 4 . \mathrm{VS} 018.8 \pm 4.2, \mathrm{P}=$ 0.43 ) and underlying diseases. Less cough was noted in RF group (odd ratio 4.55, 95\%CI 1.19-100.00, $\mathrm{P}=0.04$ ). RF patients had higher admission SOFA score $(4.3 \pm 3.6$ VS $2.2 \pm 2.1, \mathrm{P}=0.007)$ and the score progressively increased in $45.7 \%$ of patients. The presence of military infiltration or cavitation were found in only one third of the patients. With certain limitation, conventional anti$\mathrm{TB}$ regimens were given in only $51.4 \%$ of RF patients. Consequently, Patients with RF had higher hospital mortality $(51.4 \%$ VS $12 \%, \mathrm{P}=0.002)$.

\section{Conclusions}

Substantial proportion of patients with newly diagnosed tuberculosis had respiratory failure. This condition was associated with higher hospital mortality. Notably, RF patients had less prominent presenting symptom, progressive deteriorated and inability to receive potent antiTB medication.

Published: 1 October 2015

doi:10.1186/2197-425X-3-S1-A391

Cite this article as: Permpikul et al:: Clinical characteristics of newly diagnosed tuberculosis patients with respiratory failure. Intensive Care Medicine Experimental 2015 3(Suppl 1):A391.
Submit your manuscript to a SpringerOpen ${ }^{\circ}$ journal and benefit from:

- Convenient online submission

- Rigorous peer review

- Immediate publication on acceptance

- Open access: articles freely available online

- High visibility within the field

- Retaining the copyright to your article

Submit your next manuscript at $>$ springeropen.com

\section{SpringerOpen ${ }^{\circ}$}

C 2015 Permpikul et al.; This is an Open Access article distributed under the terms of the Creative Commons Attribution License (http://creativecommons.org/licenses/by/4.0), which permits unrestricted use, distribution, and reproduction in any medium, provided the original work is properly cited. 